4. Vorontsov, M.A., Dudorov, V.V., Zyryanova, M.O., Kolosov, V.V., Filimonov, G.A. Bit error rate in free-space optical communication systems with a partially coherent transmitting beam. Atmospheric and Oceanic Optics. Vol. 26. (2013). 185-189.

5. Majumdar, A.K.: Fundamentals of Free-Space Optical (FSO) Communication System.(2015).

6. Kaushal, H., Kaddoum, G.: Free Space Optical Communication: Challenges and Mitigation Techniques. (2015).

DOI https://doi.org/10.30525/978-9934-26-109-1-16

\title{
МЕТОДИ АПРОКСИМАЦІЇ БІОЛОГІЧНИХ СИГНАЛІВ ЗА ДОПОМОГОЮ ФУНКЦЙ ГАУСА
}

\author{
Мосьпан Д. В. \\ кандидат технічних наук, \\ дочент кафедри електронних апаратів \\ Кременчуцький національний університет \\ імені Михайла Остроградського \\ Мосьпан В. O. \\ кандидат технічних наук, \\ доиент кафедри електронних апаратів, \\ декан факультету електроніки та комп 'ютерної інженерії \\ Кременчуиький національний університет \\ імені Михайла Остроградського \\ Юрко О. О. \\ кандидат технічних наук, \\ дочент кафедри електронних апаратів \\ Кременчуиький національний університет \\ імені Михайла Остроградського \\ м. Кременчук, Україна
}

У даний час в медицині все більш широке застосування знаходить метод математичного аналізу різних біологічних сигналів. Більшість з них є випадковими та квазіперіодичними процесами, що значно 
ускладнює можливість використання автоматизованого процесу обробки даних. До сигналів такого типу можна віднести дихальні шуми, фонокардіографічні та електрокардіографічні сигнали.

Форма зубців ЕКГ сигналу досить точно описується несиметричними імпульсами Гаусса. При цьому можна досягти необхідну точність апроксимації, шляхом введення додаткових імпульсів для опису діагностично важливих неоднорідностей сигналу [1].

У роботах описана методика розрахунку і підбору коефіцієнтів функцій Гаусса [2; 3]. Також в [4] реалізований простий алгоритм підбору коефіцієнтів несиметричних функцій у вигляді віртуального приладу Labview. Але для випадків накладання різнополярних зубців і нестандартних форм імпульсів, результат застосування даного алгоритму дає значну похибку.

У даній роботі зроблена спроба удосконалити віртуальний прилад для автоматичного визначення параметрів апроксимуючих несиметричних кривих Гаусса в програмному середовищі Labview.

Основою для визначення параметрів імпульсу був узятий вбудований віртуальний прилад (ВП) для симетричних функцій Гаусса.

Розроблений віртуальний прилад було використано для аналізу біологічних сигналів (зокрема дихальних шумів та фонокардіосигналів).

Для дихального циклу аналітичний вираз загальної обвідної сигналу можна представити у вигляді:

$$
Y(n)=\sum_{k=1}^{N} Y_{k}(n)=\sum_{k=1}^{N} A_{k} e^{-\frac{\left(n-n_{m k}\right)^{2}}{2 \sigma^{2}},}, \begin{aligned}
& \sigma=\sigma_{1 k}, n<n_{m}, \\
& \sigma=\sigma_{2 k}, n \geq n_{m}
\end{aligned} .
$$

де А - коефіцієнт верхівки зубця; $\sigma_{1}, \sigma_{2}$ - коефіцієнти, за допомогою яких можна пристосувати дану залежність до експериментальної кривої; мають сенс середньоквадратичного відхилення; $\mathrm{n}$ - номер відліку за часом, $\mathrm{n}_{\mathrm{m}}$ - номер відліку, що відповідає середині зубця.

При використанні запропоновано алгоритму для апроксимації більш складних комбінацій послідовності біологічних сигналів були виявлені значні недоліки при ускладненні форми імпульсів.

При аналізі зубців негативної полярності, присутність додатного сплеску навіть незначної величини, призводить до повного ігнорування негативного зубця. Для усунення цього недоліка необхідно визначити максимальне та мінімальне значення амплітуд відліків даної ділянки та порівняти їхні абсолютні значення. Більше значення буде визначати полярність зубця, що надходить для аналізу до віртуального приладу.

66 
Наступне ускладнення - це наявність широкої пласкої вершини зубця при зміщеному максимальному значенню на крайні відліки. При цьому відбувається суттєве зміщення симетрії зубця i, як наслідок, некоректне визначення параметрів для широкої частини імпульсу. Для усунення цього недоліка пропонується визначити усі впливові екстремуми, та змістити центр симетрії на середину пласкої вершини зубця. Вбудований ВП «Peak Detector» видає значення та розташування усіх екстремумів масиву відліків. Уведення порогової межі на рівні 0,9 від максимального значення дозволяє відсіяти випадкові сплески та виділити відліки вершини. Далі визначається середина вершини. Округлення отриманого значення до найближчого цілого і $є$ номером відліку, що відповідає центру вершини зубця. Якщо ж зубець має форму з плавним зростанням фронтів на загострену вершину з одним піковим значенням, то даний алгоритм не виконується.

Блок діаграма віртуального приладу, що реалізує зазначену послідовність дій наведена на рис. 1.

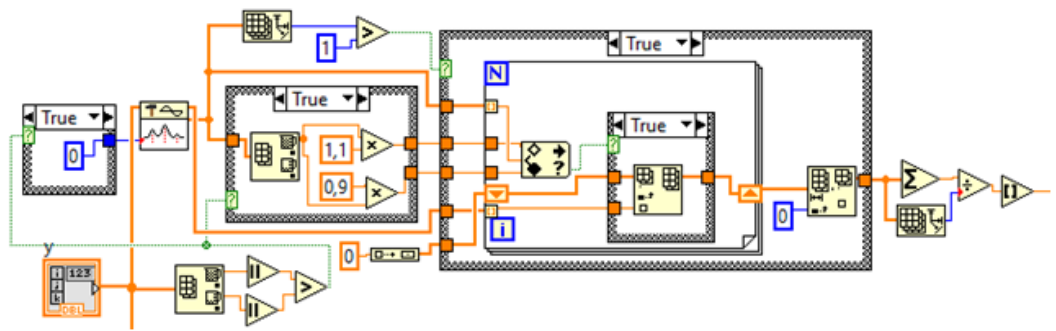

Рис. 1. Фрагмент блок діаграми для апроксимації зубців при наявності сплесків протилежної полярності

У випадку, коли зубець має значне порушення симетрії, то можливий випадок, що ВП «Gaussian Peak Fit» визначає середини та амплітуди лівих на правих частин зі значним відхиленням від реального пікового значення. Це спричинено тим, що до ВП для аналізу надходить лише та частина відліків, що відповідає наростаючому або спадаючому фронту до пікового значення. Причому аналіз та апроксимація двох частин виконується незалежно. Усереднення амплітудних значень та їх положень за відліками спричиняє зсув реального зубця та функції апроксимації. Для запобіганню зсуву вершин функцій Гауса відносно реального максимума $\mathrm{n}_{\mathrm{m}}$ було запропоновано дзеркально дублювати масиви даних, що відповідають лівій $\mathrm{Y}_{\mathrm{L}}[\mathrm{n}]$ та правій $\mathrm{Y}_{\mathrm{R}}[\mathrm{n}]$ частинам зубця. 
При цьому до ВП «Gaussian Peak Fit» надходять масиви даних повноцінних симетричних імпульсів з явним положенням вершини зубця, що створює умови для співпадання вершин лівих та правих частин автоматично визначених Гаусових функцій. Даний алгоритм наведено на частині блок схеми на рис. 2.

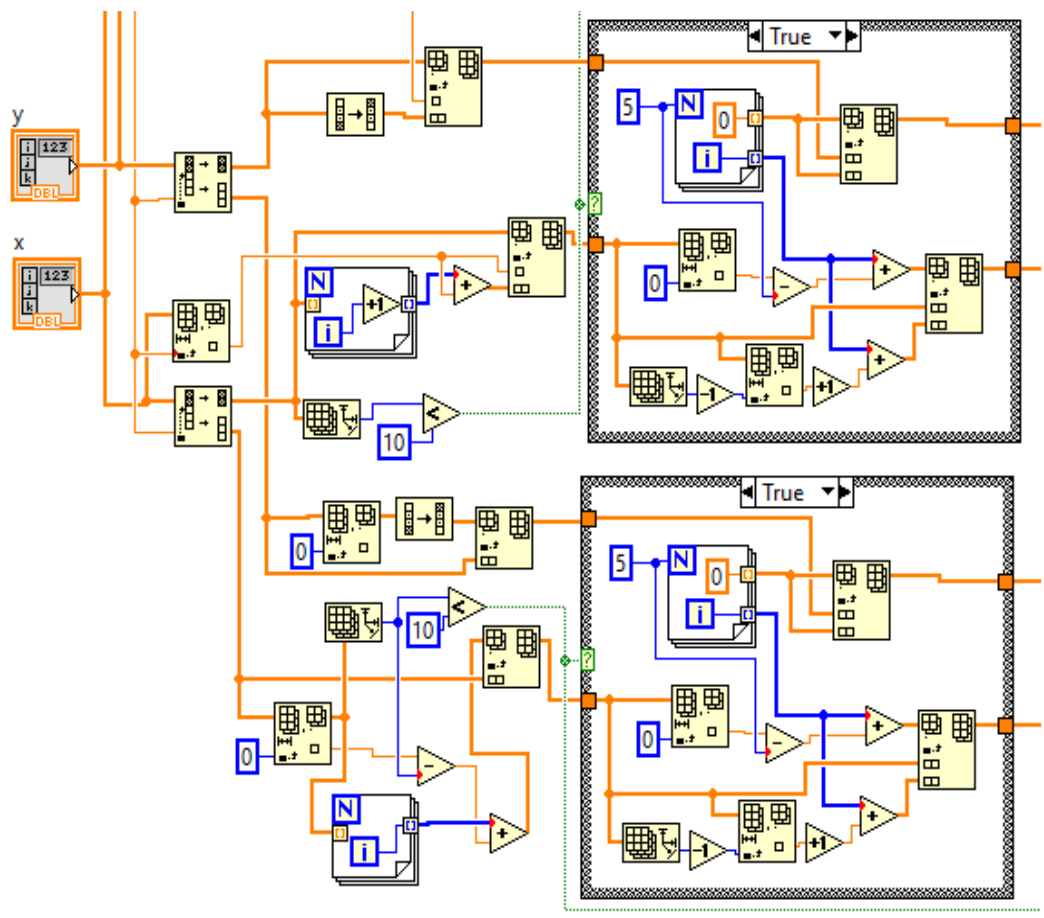

\section{Рис. 2. Фрагмент блок діаграми для апроксимації зубців 3 широкою пласкою вершиною при зміщеному максимальному значенню}

Була виявлена низька точність апроксимації у випадку вузьких фрагментів зубців, при цьому масиви даних половинок зубців, що надходять для аналізу до ВП не перевищують 10-ти відліків. Для збільшення кількості відліків запропоновано доповнювати виділені фрагменти масивів даних нульовими відліками. Прийнятні результати були отримані при симетричному доповненні фрагментів зубців п'ятьма нульовими відліками з кожної сторони. 
Відповідний алгоритм показаний на рис. 2 в структурах «Case», які виконуються у випадку, коли кількість відліків фрагменту не перевищує 10-ти.

Подальша обробка даних зводиться до роботи вбудованих ВП «Gaussian Peak Fit», співставленню згенерованих функцій апроксимації частин зубців, шляхом усереднення значень коефіцієнтів амплітуд та середин імпульсів, групування розрахованих коефіцієнтів до кластеру даних та видаленню надлишкових допоміжних значень відліків, що додавалися раніше за необхідності.

Приклад роботи створеного ВП наведений на рис. 3. На верхньому графіку показаний вхідний зубець (білим кольором з виділеними точками даних) та остаточний результат апроксимації. На нижніх графіках зображений результат розбивання зубця за фронтами на два окремих дзеркальних зубці з апроксимацією їх симетричними функціями Гауса. Параметри зубця після об’єднання виведені у кластер даних.

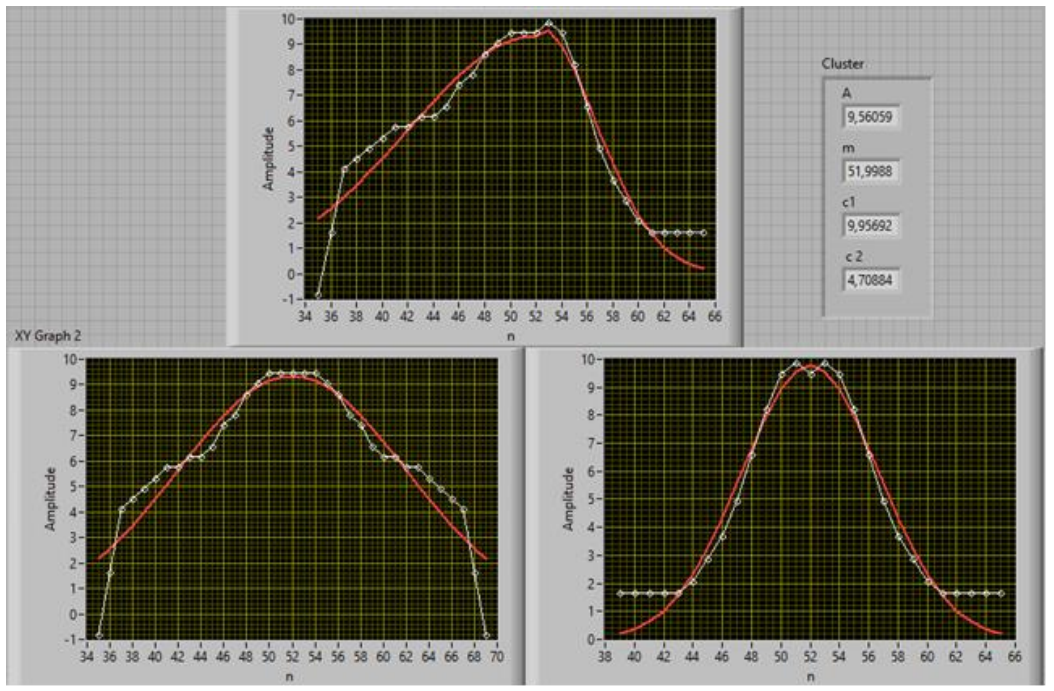

Рис. 3. Приклад обробки даних та апроксимація окремого зубця

Запропонований алгоритм було апробовано для аналізу шести грудних відведень кардіоциклу (V1...V6) ЕКГ сигналу. Результати проведеної апроксимації наведені на рис. 4. Тонкими білими лініями показані вхідні дані масивів грудних відвідень, а товстими лініями результати апроксимації несиметричними функціями Гауса. 


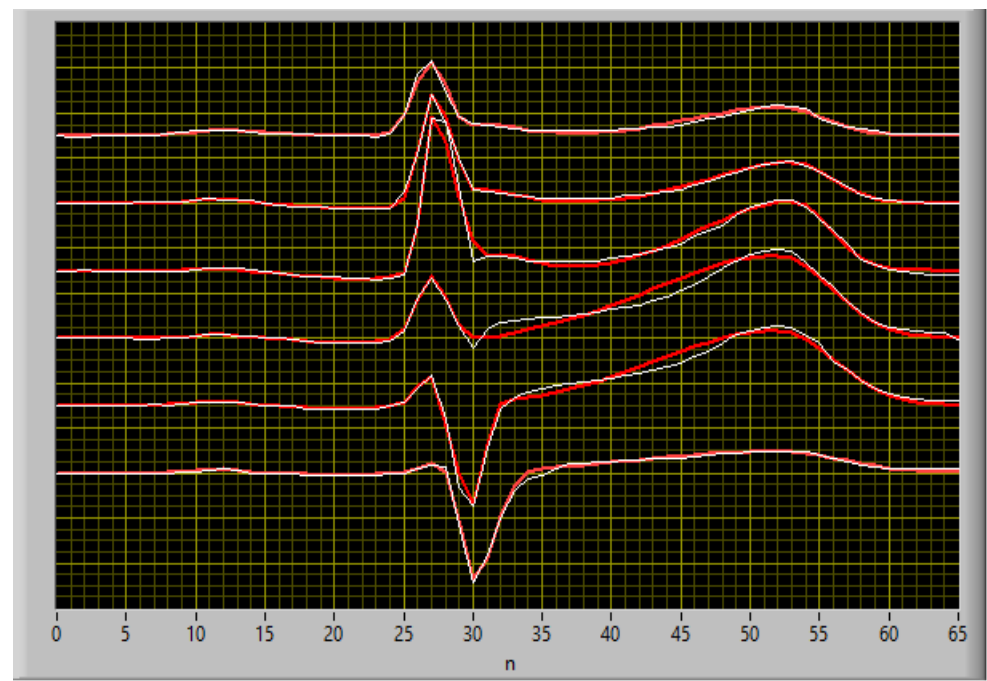

Рис. 4. Результати апроксимації шести грудних відведень ЕКГ сигналу

Для кожного відведення було розраховано коефіцієнт кореляції, значення яких є близькими до 1. Це вказує на прийнятний загальний результат апроксимації.

Візуально можна спостерігати локальні недоліки, особливо в місцях пологих фронтів зубців при наявності добре виражених точок перегину та положення сегменту ST. Розташування останнього відносно ізолінії містить діагностичну інформацію [5]. Це відповідно потребує подальшого доопрацювання алгоритму апроксимації.

В результаті було удосконалено алгоритм для апроксимації біологічних сигналів несиметричними функціями Гауса. Збільшена впевненість апроксимації зубців при наявності: сплесків протилежної полярності; широкої пласкої вершини зубця при зміщеному максимальному значенню на крайні відліки; значного порушення симетрії зубців; вузьких фрагментів зубців.

Створено віртуальний прилад для апроксимації сигналів (зокрема відведень ЕКГ сигналів, обвідних дихальних шумів та фонокардіосигналів) за допомогою несиметричних функцій Гауса. Аналіз визначених коефіцієнтів дозволить використовувати їх в якості усереднених критеріїв для діагностики відповідних захворювань, що потребує подальших досліджень. 
Необхідне подальше удосконалення даного алгоритму, зокрема при наявності пологих фронтів зубців з добре вираженими точками перегину та шляхом збільшення вибірки статистичного аналізу експериментальних даних.

\section{Література:}

1. Никифоров П. Л. Модель электрокардиографического сигнала на основе совокупности колокольных импульсов. Вестн. молодых ученыхх. Сер. Техн. науки. 1998. № 1. С. 64-68.

2. Абрамов М. В. Аппроксимация экспонентами временного кардиологического ряда на основе ЭКГ. Вестник кибернетики. 2010. № 9. C. 85-91.

3. Кочергіна С. С., Юрко О. О. Апроксимація ЕКГ сигналу «зміненими» гаусовими імпульсами зі збереженням діагностичноважливих точок. Вісник КрНУ ім. М. Остроградського. № 3/2012 (74). 2012. С. 58-61.

4. Голодний Р. А., Юрко О. О. Апроксимація обвідної акустичних сигналів. Актуальные научные исследования в современном мире: ХХХІІІ Международная научная конференция (26-27 января 2018 г.): Сборник научных трудов. № 1(33), ч. 8. Переяслав-Хмельницкий, 2018. C. $101-107$.

5. Баткин И. 3. Введение в клиническую электрокардиографию. Интерактивная лекция для студентов и врачей общей практики. URL: http://www2.fesmu.ru/PolTxt/U0013/ecgLecture/lecture1.htm. (Дата звернення: 20.05.2021). 